Volume 6, Issue 4, 407 - 417.

ISSN: $2165-8714$

http://www.eu-jer.com/

\title{
The Impact of Conversations on Fourth Grade Reading Performance - What NAEP Data Explorer Tells?
}

\author{
Jeremy Bond \\ Central Michigan University, USA
}

\author{
Mingyuan Zhang * \\ Central Michigan University, USA
}

Received: August 20, 2017 - Accepted: October 11, 2017

\begin{abstract}
This study presented a secondary analysis of the National Assessment of Educational Progress (NAEP) dataset. The paper explored the differences between fourth grade reading scores by examining (1) how often the fourth graders discuss their school work at home with family and (2) how often the fourth graders discuss what they were reading with friends. The results by NAEP Data Explorer indicate that the average scale score $(M=214, S D=36)$ of students who report "never or hardly ever" talking about studies at home was significantly $(\mathrm{p}<0.001)$ lower than all other groups. The results of how often they talked to their friends about what they were reading were mixed: Students reporting talk with friends once or twice a month $(M=228, S D=35)$ had significantly $(p<0.001)$ higher average scale scores than those in the never or hardly ever and almost every day groups and slightly lower than those talking once or twice a week.
\end{abstract}

Keywords: Reading performance, National Assessment of Educational Progress, NAEP.

To cite this article: Bond, J., \& Zhang, M. (2017). The impact of conversations on fourth grade reading performance - What NAEP data explorer tells? European Journal of Educational Research, 6(4), 407-417. doi: 10.12973/eu-jer.6.4.407

\section{Introduction}

Conventional wisdom has long suggested that reading to young children is beneficial to their cognitive development as well as their performance in school settings. However, as children transition from a period of learning to read, to one of reading to learn, a parent's involvement in reading with their elementary aged-children, often declines. Klauda (2009) acknowledged the significant research focus placed upon the role of parents in the learning of children in preschool and primary grades as well as the decline of this focus in the research relative to learner age advancing beyond primary school. Fourth graders, in particular, the youngest group investigated by Klauda, are in this transitional space. Fourth graders are obviously not the youngest learners, but they are also not yet adolescents. Nonetheless, they generally are reading to learn at this stage, not learning to read. Additionally, friendships and social connections begin to play a more significant role in the lives of children at this stage. Vygotsky $(1978,1981)$ concluded in part that personal communications - such as those which one has with friends - play a key role in learning.

The purpose of this research is to explore the relationships between recent NAEP fourth grade reading scores and conversation related to reading and school work at home and in social settings. As the majority of an American elementary school student's time is invested away from school, and nearly one in five students is low performers in reading, it is reasonable to explore actions outside of school which may improve student performance in reading (OECD, 2016). Moreover, significant research exists which indicates the value of parental involvement in student learning, as well as the positive impact of a student's own interaction with peers, can also have on their learning (Ivey, 2014; Feiker Hollenbeck, 2013; Reglin, Cameron, \& Losike-Sedimo, 2012). Given the conclusion of these researchers and others, a positive relationship should exist between beyond school factors and student reading test scores. However, much of the current research, respectively, investigates highly prescribed strategies (Jackson, 2016 \& Bacon, 2005) and often relies on classroom settings (Sanden, 2012), or close relationships, and ongoing communication, between home and school (Reglin, Cameron, \& Losike-Sedimo, 2012).

Though the focus of this research may ostensibly suggest an audience exclusively of parents and guardians of middle elementary learners, the appeal more broadly extends to teachers, school administration, and perhaps even to learners themselves, as all share in the common goal of improving crucial literacy skills in our population. This research seeks to answer the following questions:

\footnotetext{
* Corresponding author:

Mingyuan Zhang, Central Michigan University, USA

Email: zhang1m@cmich.edu
} 
Do fourth-grade learners discuss their school work at home/with family?

Do fourth-grade learners discuss what they are reading with friends?

What relationship or impact do these conversations, if they are occurring, have on fourth-grade reading test scores?

By investigating these factors and relationships, the researcher intends to suggest practical strategies which can contribute to improved literacy skills, greater reading comprehension, and higher test scores. These strategies may lend themselves to use by teachers, through school-home partnerships, and/or by parents interacting with their children.

Our theoretical framework for this research adopts a scientific inquiry-based approach. The Scientific inquiry-based approach, according to the National Science Education Standards (NRC, 1996), the Benchmarks of Science Literacy (AAAS, 1994), International Society for Technology in Education, (ISTE, 2014), and Next Generation Science Standards (NGSS, 2013), is investigation driven and science process initiated. It also goes beyond the mere development of process skills such as observing, inferring, questioning, interpreting and analyzing data. It combines these processes with scientific knowledge, scientific reasoning, and critical thinking to develop scientific knowledge (Lederman, Antink, \& Bartos, 2014). Scientific inquiry will guide us in examining the nature of the data (Yao, Zhong, \& Zhao, 2008). By following the scientific inquiry, we will begin with an extensive exploration of the dataset (NAEP) and then design our data-based research questions to mine the data systematically since there is no single set of sequential steps to follow in the scientific inquiry (Lederman et al., 2014; Sandoval, 2005). The focus of the research is the goal of the data mining - the discovery of knowledge from data (Piatetsky-Shapiro, 1996). With the scientific inquiry-based approach and data mining focus, we established our theoretical framework for this quantitative data mining research.

\section{Review of Literature}

According to a 2016 report from the Organization for Economic Cooperation and Development (OECD), 17\% of U.S. students were low performers in reading, compared with an average $18 \%$ value in OECD data overall. While arguably favorable, this information simultaneously highlights the need for improvement. However, the influence of the classroom experience, already taxed by restricted funding, and various other challenges are limited. In terms of time, the typical American grade-school student is in school an average of just 943 hours per year. Within this constraint, obviously, only a portion of the hours can be dedicated to reading and related skills. This indicates a need to focus on the impact of non-school factors, which represent nearly ninety percent of a student's time - time away from school, to explore the significant impact of non-school activities on their performance. Moreover, investigating the nature of effective strategies and translating these into action will also prove useful in impacting student reading performance.

\section{Effective Interventions for Literacy Learning}

Reading, if one is to understand and learn from reading, requires multiple cognitive processes to occur in tandem. Kiefer, Vukovic, and Berry (2013) advise that "reading comprehension is a complex and multifaceted cognitive process that draws on a wide range of skills" (p. 333). Specifically, executive function and higher order cognition, involving working memory, attention shifting, and inhibitory control, play important roles in comprehension. It is reasonable to describe reading as an evolutionary process involving interaction among reader, text, and an activity, situated within a particular sociocultural context (Kiefer, Vukovic \& Berry, 2013).

Therefore, the most effective impacts on reading comprehension will be those which create or leverage an existing and safe social context, as well as provide for a variety of interaction, stretching beyond a student's own quiet reading of a text. Teachers then are in place to support students in bridging the gap between what students may already know and what else they need to know to succeed (Bacon, 2005). This gap, of course, is better known as Vygotsky's zone of proximal development. Knowing the elements of what can serve to support and expand a student's understanding, to identify the student's zone of proximal development and further their comprehension when reading is only a part of a larger picture, as is the teacher's role itself. Numerous other factors contribute to a student's achievement in every aspect of their learning, but perhaps no more so than in their success as readers. Generally, the most prevalent themes found in the literature are themes that address impacts on a student's life beyond the classroom, from familial and social contacts, as well as the nature of activity relating to reading in- and out-of-school which can affect their development.

\section{Family and Peer Impacts on Literacy Learning}

The family influence is a subject of great interest, as teachers possess various perspectives on precisely how the family might influence the child's academic success (Snow, Barnes, Chandler, Goodman, \& Hemphill, 1991). Though Snow, 
et.al. identified three different models through which the family could exert a positive influence on a child's learning in school, the researchers also found rather encouragingly, that regardless of specifics the "home and school relationship can be compensatory, one providing what the other fails to provide" (p. 28). Additionally, the earlier the family involvement occurs in a young learner's life, the better. Preschool children exposed regularly to picture books, with their parents' involvement showed the considerable impact on those children's achievement (Cheng \& Tsai, 2016; Lonigan \& Whitehurts, 1998). Somewhat in contrast, Reglin, Cameron, and Losike-Sedimo (2012) sought not to assess the family model's general impact or the value of informal involvement, but to test the value of a highly prescribed approach, a parent support reading (PSR) intervention, on improving scores. Following the implementation of a multiweek PSR curriculum, a large effect size was achieved (0.763) in post-test scores for students in the experimental group, as compared with those who were not. This generally supports the conclusion that "parental involvement...is necessary to reading achievement" (p. 25), and further establishes the potential value of family-specific non-school factors.

Family, however, is not the only non-school factor worthy of attention. Though somewhat less research exists pertaining to peer and social influences on younger learners' reading, there is an undeniable social aspect in play. Though Ivey (2014) studied young adolescents, only a few years separated these research subjects from fourth graders. Therefore, it is not unimaginable to consider the way "that the talk itself [about reading] changes [students'] relationships with each other" (p. 168) could just as easily have been written of fourth-graders. This process of interacting with peers about what one is reading extends the student's own thinking and carries the purpose beyond reading simply as a way to later answer questions or show understanding (Ivey, 2014). Though dialoguing about reading with peers is included here, as an element of non-school impacts, the compelling role of conversation itself can also be found in the research literature as a singular influence for consideration.

\section{Conversation, Interaction, and Literacy Learning}

The conversation around one's reading is generally accepted to be advantageous for comprehension. Moreover, conversation can serve to address numerous barriers to reading comprehension as well, including aiding students who "may lack a foundation in decoding and/or have impaired reading fluency, [have an] inability to read with sufficient accuracy, rate, and/or prosody" (Feiker Hollenbeck, 2013, p. 113). The teacher's role, especially in the in-class environment, is significant as they must first present reasons which motivate students to read and options which interest them in reading, to evolve reading into a habit and create discussion around it (Ivey, 2014). A related strategy, the think aloud "is a method widely used for instruction characterized by the teacher modeling the thinking process by verbalizing thoughts while reading aloud for students" (Dunston \& Headley, 2002 as cited in Jackson, 2016, p. 2). By engaging themselves in think aloud, students are "involved actively in the [reading] process through the guidance of the teacher" (p. 6). This guided process, itself related to the conversation in its use of verbalization, yields positive results correlating with greater comprehension (Jackson, 2016). Though think aloud is essentially a student-to-teacher exchange, peer-assisted learning strategies (PALS), which are essentially student-to-student interactions, have also been shown to yield positive results on reading comprehension and attitude toward reading (Lee, 2014). In fact, the positive results were achieved simply introducing the PAL "as a supplementary reading activity for 20 min[utes] in the morning before the regular classes begin" (p. 484). Though more structured than simple conversation, not unlike think aloud, the PAL strategy implemented in the study by Lee (2014) modeled conversation closely as "the more proficient reader reads aloud first for 2 minutes, and then the less proficient reader reads aloud the same text for 2 minutes" (p. 484). Later in the exercise, the students take turns retelling to one another and making predictions. Here again, a conversational approach has shown its valuable impact on learning.

Even in a digital context, reading on social media, and interacting via text chat, though fundamentally changing the nature of the conversation, can have a positive value. Perhaps in the way digital technologies afford a wider array of connections, the inquiry experience is enhanced by the way "Twitter and blog interactions, such as \#theglobalclassroom and many others, go beyond the social purpose to explore issues" (Van Der Westhuizen, 2013, p. 104). "Reading and typing are the forms the conversation takes, and participation is often aimed at exchanging ideas to solve problems." (p. 104). This emerging research further supports the value of dialog, even if it is not verbal. In a connected society then, Van Der Westhizen (2013) suggests teachers can take advantage of these constructs. By extension, parent and peer-interactions can likewise benefit from exchanges in digital space.

In summary, the balance between classroom and non-classroom intervention must be struck in such a way to facilitate a fluid exchange around the reading a student pursues. Whether the student discusses this reading at home, among peers, verbally, or digitally, the positive impacts are well documented. Less explored are the family- and peerinteraction elements ascertained in recent NAEP surveys and their relationship to student reading test performance. Literature investigating reading scores and NAEP data has tended in recent years toward investigations of the impact of monetary rewards, looking at much older students, in the high school arena, as well as other work merely reporting comparative data from one year to another. Other research focuses on geographic and economic disparities, leaving a 
gap for translation of the simplest interventions and their potential positive effect on students' reading into action that can occur in essentially any setting.

\section{Methods}

Data for this research was obtained from the National Center for Education Statistics' National Assessment of Educational Progress (NAEP) online database. The website's Data Explorer tools were used to procure data for Reading, at the fourth-grade level, in the 2015 test and survey results. This data was analyzed with the response data for two coded questions regarding talk about studies and reading, respectively at home and with friends.

\section{Participants and Sampling}

NCES (2016) described the sampling and data collection protocols used for collecting NAEP fourth-grade reading data. Since NCLB (2002), participation by fourth-grade students in reading assessments has been mandatory in states receiving Title I funds. All states have participated in these assessments since NCLB (2002). "The schools and students participating in NAEP assessments are selected to be representative of all schools nationally and of public schools at the state/jurisdiction and district levels." (U.S. Dept. of Education, 2015).

\section{NAEP Sampling and Data Collection}

Results for 2015 are based on samples drawn from 139,100 fourth-graders from 7,810 schools. Samples were drawn from each state in a multi-stage process that included students from selected schools in selected geographic areas (Klecker, 2014). As each school and each student assessed represents only a portion of a larger population "results are weighted to account for the disproportionate representation of some groups in the selected sample" (NAEP, 2015).

\section{Data Analysis}

The NAEP Data Explorer (NDE), a "web-based application for accessing National Assessment of Educational Progress (NAEP) data," was used to analyze data from fourth-grade schools nationwide. Average Reading scale scores and standard deviations for fourth graders in 2015 were selected for the analyses. The two coded questions selected through NDE were:

(1) How often do you talk about studies at home? Options: Never or hardly ever; Every few weeks; About once a week; 2-3 times a week; Every day [B017451]

(2) How often do you talk with friends about what you read? Options: Never or hardly ever; Once or twice a month; Once or twice a week; Almost every day [R831101]

NDE calculated and presented descriptive tables and tests of statistically significant differences. "Effect size measures either measure the sizes of associations or the sizes of differences" (Walker, 2007, n.p.) and Cohen, by providing $d$, allows comparison between two means. Cohen's $d$ is, therefore, the difference in the two groups' means divided by the average of their standard deviations (Walker, 2007).

\section{Results}

This section addresses two 2015 NAEP questions at a National level relating to fourth-grade students' reading. Specifically, the questions respectively ask students to report how often they talk about studies at home and how often they talk with friends about what they read. As a fundamental basis for comparison, the nationwide average scale score and related statistics will also be presented. Alpha was set a priori at .001 . All differences were statistically significant and effect sizes, d were calculated using an online effect size calculator (http://www.uccs.edu/ lbecker/).

\section{Data Analysis}

Table 1 presents the average scale score in 2015 for fourth grade reading at the National (nationwide) level. NAEP's Data Explorer does not include the number of students $(\mathrm{N})$. Therefore, the table below, as well as all others, in this Results and Data Analysis section, is absent the expected value (N) (Klecker, 2014; NAEP, 2016). 
Table 1. National Average Scale Score - Fourth Grade Reading

\begin{tabular}{cccccc}
\hline & & \multicolumn{2}{c}{ All students } \\
\hline Year & Jurisdiction & Average scale score & Standard Error & Standard deviation & Standard Error \\
2015 & National & 223 & $(0.4)$ & 37 & $(0.3)$ \\
\hline
\end{tabular}

NOTE: The NAEP Reading scale ranges from 0 to 500. SOURCE: U.S. Department of Education, Institute of Education Sciences, National Center for Education Statistics, National Assessment of Educational Progress (NAEP), 2015 Reading Assessment.

Scores range from 0 to 500 . The average scale score for reading for all fourth graders was 223, with a standard deviation of 37 .

Table 2. How often do you talk about studies at home?

\begin{tabular}{cccccccccc}
\hline \multicolumn{2}{c}{ Never or Hardly Ever } & \multicolumn{2}{c}{ Every Few Weeks } & \multicolumn{2}{c}{ About Once a Week } & \multicolumn{2}{c}{ 2-3 Times a Week } & \multicolumn{2}{c}{ Every Day } \\
\hline M & SD & M & SD & M & SD & M & SD & M & SD \\
214 & 36 & 219 & 36 & 227 & 36 & 234 & 33 & 221 & 38 \\
\hline
\end{tabular}

Fourth graders reporting talk about studies at the "Never or Hardly Ever" level had an average scale score of 214, $\mathrm{sd}=36$. Mean score for those reporting talk every few weeks was 219 (36). Students indicating that they talk 2-3 times a week about studies had the highest average score at 234 (33). The average scale score among students reporting talk about studies "every day" was 221 (38).

Table 3. Difference in Average Scale Scores Between Variables for Talk About Studies at Home [B017451]

\begin{tabular}{|c|c|c|c|c|c|}
\hline & $\begin{array}{c}\text { Never or hardly } \\
\text { ever } \\
(214)\end{array}$ & $\begin{array}{l}\text { Every few weeks } \\
\text { (219) }\end{array}$ & $\begin{array}{l}\text { About once a week } \\
\text { (227) }\end{array}$ & $\begin{array}{c}2-3 \text { times a week } \\
(234)\end{array}$ & $\begin{array}{c}\text { Every day } \\
\text { (221) }\end{array}$ \\
\hline $\begin{array}{c}\text { Never or hardly } \\
\text { ever } \\
(214)\end{array}$ & & $\begin{array}{c}< \\
\text { Diff }=-5 \\
\text { P-value }=0.0000 \\
\text { Family size }=10\end{array}$ & $\begin{array}{c}< \\
\text { Diff }=-13 \\
\text { P-value }=0.0000 \\
\text { Family size }=10\end{array}$ & $\begin{array}{c}< \\
\text { Diff }=-20 \\
\text { P-value }=0.0000 \\
\text { Family size }=10\end{array}$ & $\begin{array}{c}< \\
\text { Diff }=-7 \\
\text { P-value }=0.0000 \\
\text { Family size }=10\end{array}$ \\
\hline \multirow[t]{2}{*}{$\begin{array}{c}\text { Every few weeks } \\
\text { (219) }\end{array}$} & $\begin{array}{c}> \\
\text { Diff }=5 \\
\text { P-value }=0.0000 \\
\text { Family size }=10\end{array}$ & & $\begin{array}{c}< \\
\text { Diff }=-8 \\
\text { P-value }=0.0000 \\
\text { Family size }=10\end{array}$ & $\begin{array}{c}< \\
\text { Diff }=-15 \\
\text { P-value }=0.0000 \\
\text { Family size }=10\end{array}$ & $\begin{array}{c}< \\
\text { Diff }=-2 \\
\text { P-value }=0.0078 \\
\text { Family size }=10\end{array}$ \\
\hline & $\begin{array}{c}\text { Never or hardly } \\
\text { ever } \\
(214)\end{array}$ & $\begin{array}{c}\text { Every few weeks } \\
(219)\end{array}$ & $\begin{array}{l}\text { About once a week } \\
\text { (227) }\end{array}$ & $\begin{array}{c}2-3 \text { times a week } \\
(234)\end{array}$ & $\begin{array}{l}\text { Every day } \\
\text { (221) }\end{array}$ \\
\hline $\begin{array}{l}\text { About once a week } \\
\text { (227) }\end{array}$ & $\begin{array}{c}> \\
\text { Diff }=13 \\
\text { P-value }=0.0000 \\
\text { Family size }=10\end{array}$ & $\begin{array}{c}> \\
\text { Diff }=8 \\
\text { P-value }=0.0000 \\
\text { Family size }=10\end{array}$ & & $\begin{array}{c}< \\
\text { Diff }=-7 \\
\text { P-value }=0.0000 \\
\text { Family size }=10\end{array}$ & $\begin{array}{c}> \\
\text { Diff }=6 \\
\text { P-value }=0.0000 \\
\text { Family size }=10\end{array}$ \\
\hline $\begin{array}{c}\text { 2-3 times a week } \\
\text { (234) }\end{array}$ & $\begin{array}{c}> \\
\text { Diff }=20 \\
\text { P-value }=0.0000 \\
\text { Family size }=10\end{array}$ & $\begin{array}{c}> \\
\text { Diff }=15 \\
\text { P-value }=0.0000 \\
\text { Family size }=10\end{array}$ & $\begin{array}{c}> \\
\text { Diff }=7 \\
\text { P-value }=0.0000 \\
\text { Family size }=10\end{array}$ & & $\begin{array}{c}> \\
\text { Diff }=13 \\
\text { P-value }=0.0000 \\
\text { Family size }=10\end{array}$ \\
\hline $\begin{array}{l}\text { Every day } \\
\text { (221) }\end{array}$ & $\begin{array}{c}> \\
\text { Diff }=7 \\
\text { P-value }=0.0000 \\
\text { Family size }=10\end{array}$ & $\begin{array}{c}> \\
\text { Diff }=2 \\
\text { P-value }=0.0078 \\
\text { Family size }=10\end{array}$ & $\begin{array}{c}< \\
\text { Diff }=-6 \\
\text { P-value }=0.0000 \\
\text { Family size }=10\end{array}$ & $\begin{array}{c}< \\
\text { Diff }=-13 \\
\text { P-value }=0.0000 \\
\text { Family size }=10\end{array}$ & \\
\hline
\end{tabular}

\section{LEGEND:}

Significantly lower.

$>\quad$ Significantly higher.

X No significant difference.

NOTE: Within country comparisons on any given year are dependent with an alpha level of 0.05 . 
Table 3 presents differences in means and independent t-test results. Alpha was set at 0.05 rather than 0.001 as set a priori by the researcher. The average scale score $(M=214, S D=36)$ of students who report "never or hardly ever" talking about studies at home was significantly $(\mathrm{p}<0.001)$ lower than all other groups. Students reporting at home talk every few weeks $(M=219, S D=36)$ had significantly $(\mathrm{p}<0.001)$ higher average scale score than those in the never or hardly ever group, but lower than those talking once a week, 2-3 times a week, and every day. Average scale score for those reporting once a week talk about studies $(M=227, S D=36)$ was likewise higher than those talking at home "never or hardly ever" and "every few weeks" by a difference of 13 and 8 points respectively. Students reporting talk 2-3 times a week at home about their studies had the highest average scale score $(M=234, S D=33)$, significantly higher than all other groups, with a difference of up to 20 when compared with the never or hardly ever group, to a difference of only 7 in comparison with students reporting once a week talk. Results were mixed among those students reporting "every day" talk about studies. Average scale scores $(M=221, S D=38)$ were higher than those in the never or hardly ever and every few weeks group, but significantly $(\mathrm{p}<0.001)$ lower than the average in the about once a week and $2-3$ times a week datasets.

Table 4. Effect Sizes of Mean Score Differences when Talk about Studies at Home

\begin{tabular}{cccc}
\hline & & Cohen's $\boldsymbol{d}$ & Effect Size r \\
\hline Never or hardly ever & $2-3$ times a week & 0.58 & 0.28 \\
Every few weeks & $2-3$ times a week & 0.43 & 0.21 \\
About once a week & $2-3$ times a week & 0.20 & 0.10 \\
Every day & $2-3$ times a week & 0.37 & 0.18 \\
Never or hardly ever & Every few weeks & 0.13 & 0.07 \\
About once a week & Every few weeks & 0.22 & 011 \\
Every day & Every few weeks & 0.05 & 0.02 \\
About once a week & Every day & 0.16 & 0.08 \\
Never or hardly ever & Every day & 0.19 & 0.09 \\
Never or hardly ever & About once a week & 0.36 & 0.18 \\
\hline
\end{tabular}

The Cohen's d effect size between the mean score of students who indicated talk about studies at home "never or hardly ever," "every few weeks," "about once a week," or "every day" and those reported talk "2-3 times a week" were respectively $0.58,0.43,0.20$, and 0.37 . The Cohen's d effect size between the mean score of students who indicated talk "never or hardly ever," "about once a week," or "every day" and those who specified "every few weeks" were respectively $0.13,0.22$, and 0.05 . Comparison between fourth graders who reported talking about their studies "every day" and those who indicated "about once a week" or "never or hardly ever" yielded Cohen's d effect sizes of 0.16 and 0.19 respectively. The Cohen's d effect size between the "never or hardly ever" and "about once a week" groups was 0.36. The highest effect size $d=0.58$, was between the mean scale scores of fourth graders who conveyed "never or hardly ever" and "2-3 times a week", is considered a medium effect size (Cohen, 1988).

Table 5. How often do you talk with friends about what you read?

\begin{tabular}{cccccccc}
\hline \multicolumn{2}{c}{ Never or Hardly Ever } & \multicolumn{2}{c}{ Once or Twice a Month } & \multicolumn{2}{c}{ Once or Twice a Week } & \multicolumn{3}{c}{ Almost Every Day } \\
M & SD & M & SD & M & SD & M & SD \\
220 & 34 & 228 & 35 & 231 & 36 & 213 & 40 \\
\hline
\end{tabular}

Fourth graders reporting talk about reading with friends at the "Never or Hardly Ever" level had an average scale score of 220, sd=34. Mean score for those reporting talk once or twice a month was 228 (35). Students indicating they talk once or twice a week with friends about reading had the highest average score at 231 (36). The average scale score among students reporting talk about what they read "almost every day" was 213 (40). 
Table 6. Difference in Average Scale Scores Between Variables for Talk About Reading with Friends [R831101]

\begin{tabular}{|c|c|c|c|c|}
\hline & $\begin{array}{c}\text { Never or hardly ever } \\
(220)\end{array}$ & $\begin{array}{l}\text { Once or twice a month } \\
\qquad(228)\end{array}$ & $\begin{array}{c}\text { Once or twice a week } \\
\text { (231) }\end{array}$ & $\begin{array}{c}\text { Almost every day } \\
\text { (213) }\end{array}$ \\
\hline $\begin{array}{c}\text { Never or hardly ever } \\
\text { (220) }\end{array}$ & & $\begin{array}{l}< \\
\text { Diff }=-8 \\
\text { P-value }=0.0000 \\
\text { Family size }=6\end{array}$ & $\begin{array}{l}< \\
\text { Diff }=-11 \\
\text { P-value }=0.0000 \\
\text { Family size }=6\end{array}$ & $\begin{array}{l}> \\
\text { Diff }=7 \\
\text { P-value }=0.0000 \\
\text { Family size }=6\end{array}$ \\
\hline $\begin{array}{l}\text { Once or twice a month } \\
\qquad(228)\end{array}$ & $\begin{array}{l}> \\
\text { Diff }=8 \\
\text { P-value }=0.0000 \\
\text { Family size }=6\end{array}$ & & $\begin{array}{l}< \\
\text { Diff }=-3 \\
\text { P-value }=0.0001 \\
\text { Family size }=6\end{array}$ & $\begin{array}{l}> \\
\text { Diff }=15 \\
\text { P-value }=0.0000 \\
\text { Family size }=6\end{array}$ \\
\hline $\begin{array}{c}\text { Once or twice a week } \\
\text { (231) }\end{array}$ & $\begin{array}{l}> \\
\text { Diff }=11 \\
\text { P-value }=0.0000 \\
\text { Family size }=6\end{array}$ & $\begin{array}{l}> \\
\text { Diff }=3 \\
\text { P-value }=0.0001 \\
\text { Family size }=6\end{array}$ & & $\begin{array}{l}> \\
\text { Diff }=18 \\
\text { P-value }=0.0000 \\
\text { Family size }=6\end{array}$ \\
\hline $\begin{array}{c}\text { Almost every day } \\
\text { (213) }\end{array}$ & $\begin{array}{l}< \\
\text { Diff }=-7 \\
\text { P-value }=0.0000 \\
\text { Family size }=6\end{array}$ & $\begin{array}{l}< \\
\text { Diff }=-15 \\
\text { P-value }=0.0000 \\
\text { Family size }=6\end{array}$ & $\begin{array}{l}< \\
\text { Diff }=-18 \\
\text { P-value }=0.0000 \\
\text { Family size }=6\end{array}$ & \\
\hline
\end{tabular}

\section{LEGEND:}

$<\quad$ Significantly lower.

$>\quad$ Significantly higher.

$\mathrm{X} \quad$ No significant difference.

NOTE: Within country comparisons on any given year are dependent with an alpha level of 0.05 .

Table 6 presents differences in means and independent t-test results. Alpha was set at 0.05 rather than 0.001 as set a priori by the researcher. The average scale score $(M=220, S D=34)$ of students who report "never or hardly ever" talking about what they read with friends significantly $(\mathrm{p}<0.001)$ lower than that of those in the once or twice a month and once or twice a week groups, but higher than that of those reporting talking to friends about what they read almost every day. Students reporting talk with friends once or twice a month $(M=228, S D=35)$ had significantly $(p<0.001)$ higher average scale scores than those in the never or hardly ever and almost every day groups, but slightly lower than those talking once or twice a week. In addition, average scale score for those reporting once or twice a week talk $(M=231, S D=36)$ were higher than scores in all other groups. The largest difference, of 18, exists between the group reporting once or twice a week and those fourth graders who indicated "almost every day."

Table 7. Effect Sizes of Mean Score Differences when Talk with Friends about What They are Reading

\begin{tabular}{cccc}
\hline & & Cohen's $\boldsymbol{d}$ & Effect Size r \\
\hline Never or hardly ever & Once or twice a week & 0.31 & 0.16 \\
Once or twice a month & Once or twice a week & 0.08 & 0.04 \\
Almost every day & Once or twice a week & 0.47 & 0.23 \\
Never or hardly ever & Once or twice a month & 0.23 & 0.12 \\
Never or hardly ever & Almost every day & 0.19 & 0.09 \\
Once or twice a month & Almost every day & 0.40 & 0.20 \\
\hline
\end{tabular}

The Cohen's d effect size between the mean score of students who indicated talk about studies at home "never or hardly ever," "once or twice a month," or "every day" and those who reported talk "once or twice a week" were respectively $0.31,0.08$, and 0.47 . The Cohen's d effect size between the mean score of students who indicated talk "never or hardly ever," and those who specified "once or twice a month" or "almost every day" were respectively 0.23 and 0.19 . Comparison between fourth-graders' average scale scores among those who reported talking about their reading with friends "almost every day" and those who indicated "once or twice a month" produced a Cohen's d effect size of 0.40. The highest effect sizes, $d=0.47$, and $d=0.40$ were between the mean scale scores of fourth graders who respectively conveyed "almost every day" and "once or twice a week" and "almost every day" and "once or twice a month." All Cohen's d effect sizes, even the aforementioned largest among this set, are considered small (Cohen, 1988).

\section{Discussion}

At the heart of this research existed a single inquiry which cuts across the query of non-school factors of home and friend influence on fourth-grade students' reading scores. This single question is essential: Does talking about reading 
matter? The findings of this research suggest that talk does matter; though it may not have an overwhelming impact, nor does talk have an impact which is equal in all cases. Nevertheless, within these findings is inherent agreement with the discoveries of earlier research and even perhaps a call to action.

Of particular note are two findings within the analysis. First, between fourth graders who reported talking about what they are reading with parents "never or hardly ever" and those indicating talking "2-3 times per week" a Cohen's d value of 0.58 existed. Subsequent to this result is another of note in the comparison of students discussing reading with friends "almost every day" versus "once or twice a week," wherein a Cohen's d value of 0.47 was noted.

Cohen's d values are generally interpreted as small (0.2), medium (0.5), or large (0.8) (Magnusson, 2014), though Cohen (1977) advised of the "dangers" of these rough generalizations, in essence calling for closer examination. Baguley (2009) further supports this notion that results need to be interpreted for practical significance. Identifying these two Cohen's d values approximately as medium does little to identify practical significance nor does it provide needed context, making further interpretation crucial.

Considering first the 0.58 value, it can be determined from such a figure that approximately $70 \%$ of fourth graders who talk 2-3 times per week about reading with their parents would outscore those who report doing so never or hardly ever (Magnusson, 2014). The higher performance among those students talking regularly with their parents is consistent with findings supporting positive effect achieved as a result of parental involvement from Reglin, Cameron, \& Losike-Sedimo (2012), despite the formality of the conversation being an unknown in the case of NAEP data. Moreover, this stands as further support for findings from Lonigan and Whitehurts (1998) as well as Cheng and Tsai (2016) which assert improved student performance as a result of even casual parental involvement. These findings, however, would also suggest students talking more with their parents about reading (i.e. "every day") should earn even higher reading test scores; yet, they do not. In fact, fourth graders reporting daily talk with parents earned average scores thirteen points lower than those in the 2-3 times per week group and two points lower than the overall average. If talk is good, wouldn't more talk have to be better? What then accounts for this rather unexpected result? Perhaps there exists a sort of Goldilocks effect, wherein a "just right" level of talk or reading involving parents exists. Equally likely is the potential for fourth graders - who are likely learning about concepts such as exaggeration and hyperbole to engage in them, thereby misreporting their own experience on the survey, and potentially calling everything into question. Let us instead consider the apparent merit in parental involvement in student reading performance and specifically in the form of talk. If speaking to fourth-grade children 2-3 times per week can improve scores, it may be useful to have a useful framework to lend structure to that talk. As one example for consideration, Lennon and Burdick (2004) indicate the Lexile framework as a way to effectively converse with students about their reading and further that the technique is readily adaptable for use by educators and parents alike.

As variable as the question of the positive impact of talk between parent and student may be, the inquiry around peer interaction is even murkier. As noted earlier, the largest Cohen's d (0.47) existed between fourth graders reporting talk with friends "almost every day" versus "once or twice a week," wherein students in the latter group earned average scores 18 points higher than the former. The Cohen's d of 0.47 indicates roughly two-thirds of the fourth graders discussing what they are reading with peers once or twice a week will have earned higher reading scores than those claiming to discuss reading with friends almost every day. In one sense, these muddled results are consistent with findings from Ivey (2014) wherein peer conversation about reading tended to elevate the purpose of the reading and even positively impact peer-relationships; other impacts were lacking. Perhaps then the greatest value found in fourth graders talking with peers about what they are reading is in establishing positive peer influence and through that emerges the recognition of reading's value.

Curiously, across both sets of values, students who reported the most frequent talk about reading - be it with parents or friends - earned lower scores, on average, than those across the entire group, as well as lower scores than those indicating moderate amounts of discussion, on a weekly or monthly basis. This may hint at the importance of findings in other earlier research, especially that of Dunston and Headley (2002) and Jackson (2016) which encourage use of think-aloud strategies in the classroom, but especially Snow et.al. (1991) suggesting a balance be struck between the classroom environment and that beyond the classroom. Therein is an apparent call to action for parents to speak regularly with their children about what they are reading and for teachers a complimentary charge to create scenarios which will promote such interactions at home. Furthermore, in class peer reading groups and strategies which prompt interaction among students can also extend and elevate reading's value and student performance.

The intersection of environment, talk, and reading performance indicates a need for further research into which specific conversational techniques - be the use of questions suggested by the textile framework - or other strategies, can yield the best results. Furthermore, while the NAEP data addresses the student-reported frequency of talk about reading, with parents and friends, no insight into the duration, exact timing, or even tone of such conversation is 
available. Further investigation into any or all of these areas stands to deliver further insight into the ways non-school factors can support what occurs in the classroom and positively impact student performance.

\section{Conclusion and Implications}

The purpose of this study was to explore the relationship between specific non-school factors, fourth-grade student interaction with parents and friends, and NAEP reading test scores. As Klecker (2014) notes, NAEP data is valuable to researchers, but the assessment of reading skill at the fourth-grade level is a late intervention relative to corrective action that may have benefited the learner's performance earlier on. With this in mind and coupled with the understanding that students spend vastly more time out of school than in, it is valuable to explore non-school factors. In fact, the limitations of this investigation suggest looking at additional non-school factors would also be useful. In this way, it may be discovered which non-school factors might couple or exist as a set of conditions which most relate to higher reading scores and the improved academic performance associated with them.

Nevertheless, this focus on conversational factors did prove useful on its own. After all, conventional wisdom indicates reading to children is valuable, so then should talking to children about what they themselves are reading be likewise of value. Fourth graders, as noted, are generally no longer learning to read, but instead reading to learn. They are also likely establishing friendships and enjoying the early stages of social life.

These aforementioned factors further support the relevance in exploring their talk of reading - both with parents and friends. In the latter case, this research supports the findings of Snow, Barnes, Chandler, Goodman, and Hemphill (1991) in the notion that the exact structure of the parent-child conversation about reading is less important than the conversation's very existence. This may be interpreted as a charge to parents and guardians to talk to their children about what they are reading, and, given the highest average scores among fourth graders indicating 2-3 times weekly conversations, perhaps do so deliberately two or three times each week. Though the frequency of talk is clear, the lack of specificity addressing other factors - such as the content, tenor, and depth of talk, points clearly to the need for further research. Though the use of techniques, such as those suggested by the textile framework, may be a place to start for those parents interested in capitalizing on the potential value of talk on their students' reading performance, a deeper investigation of the nature of conversation already occurring could yield additional insight. These insights, gained perhaps through a survey of parents indicating talk with their children about reading, might in turn serve to explain higher performance and themselves become part of future frameworks.

As unclear as the impact of talk with parents may be on student reading scores, that of talk with friends is even less in focus. Though the most apparent value here again appears to be among students who indicate a weekly frequency of conversation, even less is known of the necessary substance of these conversations. In other words, while much research looks at the value of prescriptive approaches of parent intervention, and bridges between the classroom and home on student reading performance, such studies of child-to-child interaction are essentially non-existent. Emerging understandings, such as those of Van Der Westhuizen (2013) suggest the influence of typed interactions, those which occur by way of blog exchanges, instant messengers and social media, such as Twitter, on learning and engagement. Even this is challenging, however, with younger learners and Internet safety concerns. Though certain in-classroom techniques, such as think and read aloud, have been shown to impact performance further research is needed first to determine what value peer discussions play at this level. If, indeed, value can be substantiated, perhaps then additional investigation can surface the nature of talk that is needed to yield meaningful results.

With interaction at home as well as among friends, qualitative research is needed to better understand what makes up the discussion of studies on the home front, as well as with friends. Findings from such research might then be paired with NAEP or other quantitative data to perhaps outline conversation guides for parents and inform both parents and teachers on the type of friend-to-friend conversation to encourage. Additional research is needed to explore deeply the nature of the conversations students have at home about reading, to more clearly identify what it is that is having an impact. In the same way, research into the student's social interactions is also lacking. Finally, the role of the classroom - or more specifically, the teacher, in creating scenarios in which talk with friends and talk at home about reading are more likely to occur, should also be further researched. Increased literacy is certainly worthy of our attention as a student's performance as a reader will have a lasting impact on their education careers and beyond.

\section{References}

American Association for the Advancement of Science. (1994). Benchmarks for science literacy. New York: Oxford University Press.

Bacon, S. (2005). Reading coaches: Adapting an intervention model for upper elementary and middle school readers. Journal of Adolescent \& Adult Literacy, 48(5), 416-427. 
Baguley, T. (2009). Standardized or simple effect size: what should be reported? British journal of psychology, 100(Pt 3), 603-17.

Cheng, K. H., \& Tsai, C. C. (2014). The interaction of child-parent shared reading with an augmented reality (AR) picture book and parents' conceptions of AR learning. British Journal of Educational Technology.

Chohan, S. K. (2011). Any letter for me? Relationships between an elementary school letter writing program and student attitudes, literacy achievement, and friendship culture. Early Childhood Education Journal, 39(1), 39-50.

Cohen, J. (1977). Statistical power analysis for the behavioral sciencies. Routledge.

Cohen, J. (1988). Statistical power analysis for the behavioral sciences (2nd ed.). Hillsdale, NJ: Lawrence Erlbaum.

Feiker Hollenbeck, A. R. (2013). Beyond talking about books: Implications of the reading comprehension instruction and pedagogical beliefs of a special educator perceived as effective. Learning Disability Quarterly, 36(2), 112-125.

International Society for Technology in Education. (2014). ISTE standards: Teachers. Retrieved from http://www.iste.org/docs/pdfs/20-14_ISTE_Standards- $\quad$ T_PDF.pdf

Ivey, G. (2014). The social side of engaged reading for young adolescents. The Reading Teacher, 68(3), $165-171$.

Jackson, V. (2016). Applying the Think-Aloud Strategy to Improve Reading Comprehension of $\quad$ Science Content. Current Issues in Education, 19(2).

Kieffer, M. J., Vukovic, R. K., \& Berry, D. (2013). Roles of attention shifting and inhibitory control in fourth-grade reading comprehension. Reading Research Quarterly, 48(4), 333-348.

Klauda, S. L. (2009). The role of parents in adolescents' reading motivation and activity. Educational Psychology Review, $21(4), 325-363$.

Klecker, B. M. (2014). NAEP Fourth-, Eighth-, and Twelfth-Grade Reading Scores by Gender: 2005, 2007, 2009, 2011, 2013. Online Submission.

Lederman, N. G., Antink, A., \& Bartos, S. (2014). Nature of science, scientific inquiry, and socio-scientific issues arising from genetics: A pathway to developing a scientifically literate citizenry. Science \& Education, 23(2), 285302.

Lederman, J. S., Lederman, N. G., Bartos, S. A., Bartels, S. L., Meyer, A. A., \& Schwartz, R. S. (2014). Meaningful assessment of learners' understandings about scientific inquiry-The views about scientific inquiry (VASI) questionnaire. Journal of Research in Science Teaching, 51(1), 65-83.

Lee, Y. (2014). Promise for Enhancing Children's Reading Attitudes Through Peer Reading: A Approach. The Journal of Educational Research, 107(6), 482-492.

Mixed Method

Lennon, C., \& Burdick, H. (2004). The lexile framework as an approach for reading measurement and success. electronic publication on www.lexile.com.

Magnusson, K. (2014). Interpreting Cohen's d effect size: An interactive visualization. Hämtat, 25(10), 2014.

NAEP (2015). Mathematics and Reading: About the 2015 Reading Assessment. Retrieved from https://www.nationsreportcard.gov/reading_math_2015/\#reading/about?grade=4

NAEP (2016). Technical Socumentation. Plausible Values Versus Individual Scores. Retrieved from https://nces.ed.gov/nationsreportcard/tdw/analysis/est_pv_individual.asp

National Research Council. (1996). National science education standards. Washington, DC: $\quad$ National Academy Press.

NCES (2016). NAEP assessment sample design 4th grade. Retrieved from http://nces.ed.gov/nationsreportcard/tdw/sample_design/ 
NGSS Lead States. (2013). Next generation science standards: For states, by states. Washington, DC: National Academies Press.

No Child Left Behind (NCLB) (2002). Act of 2001, Pub. L. No. 107-110, § 115, Stat. 1425 (2002) Retrieved from http://www2.ed.gov/policy/elsec/leg/esea02/107-110.pdf

OECD (2016). Low-Performing Students: Why They Fall Behind and How To Help Them Succeed, OECD Publishing, Paris.

Piatetsky-Shapiro, G. (1996). Advances in knowledge discovery and data mining (Vol. 21). U. M. Fayyad, P. Smyth, \& R. Uthurusamy (Eds.). Menlo Park: AAAI Press.

Reglin, G., Cameron, H., \& Losike-Sedimo, N. (2012). Effects of a parent support reading intervention on seventhgrade at-risk students' reading comprehension scores. Reading Improvement, 49(1), 17-27.

Sanden, S. (2012). Independent reading: Perspectives and practices of highly effective teachers. The Reading Teacher, 66(3), 222-231.

Sandoval, W. A. (2005). Understanding students' practical epistemologies and their influence on learning through inquiry. Science Education, 89(4), 634-656.

Snow, C.E. Barnes, W.S., Chandler, J., Goodman, I.F., \& Hemphill, L. (1991). Unfulfilled expectations:Home and school influences on literacy. Cambridge, Mass.: Harvard University Press.

U.S. Department of Education, Institute of Education Sciences, National Center for Education Statistics, National Assessment of Educational Progress (NAEP), 2015 Reading Assessments. from https://www.nationsreportcard.gov/reading_math_2015/\#reading/about?grade=4

Van der Westhuizen, G. J. (2013). Reading, social media and learning conversations. Mousaion, 31(1), 94-109.

Vygotsky, L. S. (1978). Thought and language. Cambridge, MA: MIT Press.

Vygotsky, L. S. (1981). The genesis of higher mental function. In J. V. Wertsch (Ed.), The concept of activity in Soviet psychology (pp. 144-188). Armonk, NY: Sharpe.

Walker, I. (2007). Statistics for psychology: Making sense of our world through analysis. Retrieved from http://staff.bath.ac.uk/pssiw/stats2/page2/page14/page14.html

Yao, Y., Zhong, N., \& Zhao, Y. (2008). A conceptual framework of data mining. In Data Mining: Foundations and Practice (pp. 501-515). Springer Berlin Heidelberg. 